\title{
Quantitative analysis of genetic differentiation among European and Chilean strains of Drosophila subobscura
}

\author{
MYRIAM BUDNIK, LUCÍA CIFUENTES \& DANKO BRNCIC \\ Department of Cellular Biology and Genetics, Faculty of Medicine, University of Chile, Casilla 70061, Santiago 7, Chile
}

\begin{abstract}
An analysis of the interpopulational differences observed between four European and four Chilean stocks of Drosophila subobscura, with regard to wing size, egg-to-adult development time and preadult viability, shows highly significant differences between the eight stocks irrespective of the continent from which the flies are derived. The divergence of the local populations with regard to the quantitative traits described here, supplements other evidence of interpopulational differences in mating activity, chromosomal and enzyme polymorphisms. These together indicate that the evolutionary process that promotes race formation is relatively rapid, bearing in mind that $D$. subobscura was detected for the first time in South America in 1978.
\end{abstract}

Keywords: Drosophila subobscura, European and Chilean D. subobscura, genetic differentiation in Drosophila, interpopulation differences, wing variation.

\section{Introduction}

The process of colonization of Chile in South America and of other regions of the New World by the palearctic species Drosophila suboscura, has disclosed many surprising facts.

1 On the one hand, the rapid expansion of the species after its first detection in Puerto Montt in 1978: only 2 years later, the species had already extended its distributional area as far as La Serena in the north (Lat. $29^{\circ} 55^{\prime} \mathrm{S}$ ) to Punta Arenas in the Strait of Magellan in the south (Lat. $35^{\circ} 10^{\prime} \mathrm{S}$ ) (Brncic \& Budnik, 1980; Budnik \& Brncic, 1982).

2 The ecological versatility exhibited by the species. Regions of contrasting climatic conditions have been invaded, ranging from the dry and semi-desert zones in the north, to the wet and cold forests in the south.

3 The apparently rapid genetic differentiation of the Chilean populations of $D$. subobscura as compared to the ancestral European populations, evinced by analysis of chromosomal and enzymatic polymorphisms (Prevosti et al., 1985, 1987) and quantitative characters relevant to the microdifferentiation process, such as sexual isolation (Brncic \& Budnik, 1984).

4 The rapid genetic microdifferentiation of $D$. subobscura in Chile in well-defined local populations as revealed by the study of sexual isolation (Brncic \& Budnik, 1984) and genetic polymorphisms (Prevosti et al., 1985, 1987, 1990; Brncic \& Budnik, 1987).
If we consider the above mentioned evidence, the aim of the present study was a further comparison of the process of microdifferentiation between Chilean and European populations of $D$. subobscura. Observation on the patterns of variation of wing size and of some components of fitness, such as egg-to-adult developmental time and pre-adult viability in European and Chilean stocks, are discussed.

\section{Materials and methods}

In order to investigate the differences in pre-adult viability, the egg-to-adult development time and the wing size in European and Chilean stocks of $D$. subobscura, the following stocks were employed.

1 Four European stocks originated from flies collected in Sunne (Sweden, Lat. $\left.59^{\circ} 50^{\prime} \mathrm{N}\right)$, Tübingen $(\mathrm{W}$. Germany, Lat. $48^{\circ} 31^{\prime} \mathrm{N}$ ), Cinisse (Italy, Lat. $38^{\circ} 08^{\prime} \mathrm{N}$ ), and Almería (Spain, Lat. $36^{\circ} 46^{\prime} \mathrm{N}$ ).

2 Four Chilean stocks derived from flies collected in the following localities: Coyhaique (Lat. $37^{\circ} 10^{\prime} \mathrm{S}$ ), Puerto Montt (Lat. $41^{\circ} 28^{\prime} \mathrm{S}$ ), Laja (Lat. $37^{\circ} 10^{\prime} \mathrm{S}$ ) and La Florida (Lat. $33^{\circ} 30^{\prime} \mathrm{S}$ ).

All the stocks were maintained in mass cultures for several months in our laboratory before being employed in the experiments.

The flies measured were obtained by placing 500 eggs of the same age from each stock in 10 vials, 50 
eggs per vial, each vial containing $10 \mathrm{ml}$ of basic cornmeal yeast medium for Drosophila. The eggs in the vials represented a random sample of those laid by 150 inseminated females from each stock. The vials were kept at a constant temperature of $10^{\circ} \pm 1^{\circ} \mathrm{C}$. The emerging adults were counted and recorded every day in order to estimate the preadult viability and the eggto-adult development time. We followed the method used by Pfriem (1983) for wing analysis. The left wings of 100 males and 100 females of each population were dissected and mounted on slides in Canada balsam and then observed under the microscope with an ocular micrometer of 100 divisions of $0.03 \mathrm{~mm}$ each. Two different measurements were taken: (i) wing length, from the outer margin of the anterior crossvein to the tip of the wing, and (ii) wing width, running vertical to the second logitudinal vein across the anterior end of the posterior crossvein (Fig. 1).

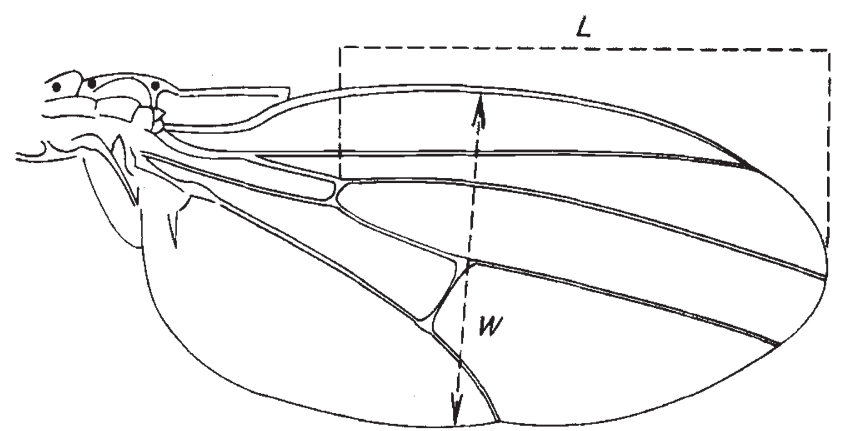

Fig. 1 Distances used to estimate wing length $(L)$ and wing width $(W)$.

\section{Results}

Table 1 shows the differences observed in wing length and wing width of the four European and four Chilean populations of $D$. subobscura. Table 2 shows the analysis of variance used to estimate the influence of continent (Europe vs. South America) and locality of origin of each stock on wing measures. Results indicated highly significant differences between the locality origin of variable, irrespective of the continent. The $F$ test applied to the Mahalonobis distance between localities (Table 3 ) shows that each locality is significantly different in respect of wing measurements, except the Almeria stock derived from the southwestern Mediterranean regions of Spain and the Chilean populations of Puerto Montt, which are not significantly different.

Wing size is a quantitative index with adaptive significance in Drosophila which responds to selection under laboratory conditions (Cavicchi et al., 1985; Cowley et al., 1986). Evidence in the literature points to inter-populational differences in wing measures in many species including $D$. subobscura. Prevosti (1955), McFarquar \& Robertson (1963), Misra \& Reeve (1964) and Pfriem (1983) found some relation between wing size and latitude. In Europe the northern populations exhibit longer and wider wings as compared to the southern population. The results in Table 1 show that the European stocks, maintained for many generations under laboratory conditions, still present the same tendency as observed in nature. The Sunne (Sweden) and Tübingen (Germany) stocks have larger wings than the Cinisse (Sicily, Italy) and Almería

Table 1 Means $(\bar{x})$ and standard errors (S.E.) of the wing length and wing width of European and Chilean populations of $D$. subobscura. (Each unit corresponds to $0.03 \mathrm{~mm}$ ) $n=$ number of measured wings

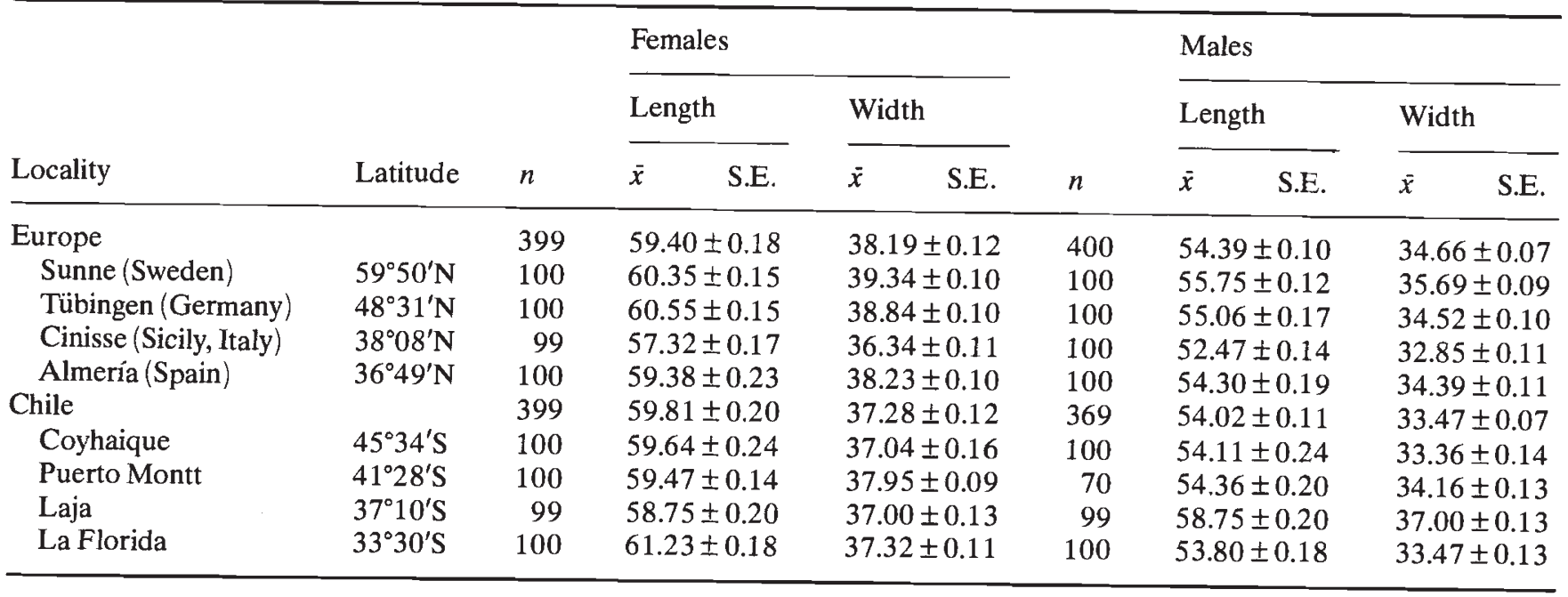


Table 2 Nested analysis of variance to estimate the influence of continent and locality within continents on length and width of wings ( $\mathrm{SS}=$ sum of squares)

\begin{tabular}{|c|c|c|c|c|c|c|}
\hline \multirow[b]{2}{*}{ Variable } & \multicolumn{2}{|c|}{ Continent $($ d.f. $=1)$} & \multicolumn{2}{|c|}{$\begin{array}{l}\text { Locality within } \\
\text { continents }(\text { d.f. }=6)\end{array}$} & \multirow{2}{*}{$\begin{array}{l}\text { Error }(\text { d.f. }=760) \\
S S\end{array}$} & \multirow{2}{*}{$\begin{array}{l}\text { Total }(\text { d.f. }=767)^{*} \\
S S\end{array}$} \\
\hline & SS & $F$ & SS & $F$ & & \\
\hline Female wing length & 28.69 & 0.18 & 970.79 & $46.24^{* *}$ & 2659.52 & 3662.07 \\
\hline Female wing width & 138.60 & 1.49 & 559.37 & $71.90^{* *}$ & 985.46 & 1703.97 \\
\hline Male wing length & 22.85 & 0.22 & 611.86 & $30.21^{* *}$ & 2565.60 & 3204.69 \\
\hline Male wing width & 133.35 & 1.76 & 453.66 & $55.74^{* *}$ & 1030.87 & 1637.87 \\
\hline
\end{tabular}

*The numbers of flies measured from some localities were less than 100; see Table 1.

$* * P<0.0001$.

Table 3 Mahalonobis distance between localities respecting wing measures ( $F$-test in parentheses)

\begin{tabular}{|c|c|c|c|c|c|c|c|c|}
\hline \multirow[b]{2}{*}{ Locality } & \multicolumn{4}{|l|}{ Europe } & \multicolumn{4}{|l|}{ Chile } \\
\hline & Sunne & Tübingen & Cinisse & Almería & Coyhaique & Puerto Montt & Laja & La Florida \\
\hline Sunne & 0 & & & & & & & \\
\hline Tübingen & $\begin{array}{r}1.579 \\
(19.44)\end{array}$ & 0 & & & & & & \\
\hline Cinisse & $\begin{array}{r}13.375 \\
(164.65)\end{array}$ & $\begin{array}{r}7.686 \\
(94.62)\end{array}$ & 0 & & & & & \\
\hline Almería & $\begin{array}{r}2.292 \\
(28.22)\end{array}$ & $\begin{array}{c}0.633 \\
(7.79)\end{array}$ & $\begin{array}{r}4.679 \\
(57.60)\end{array}$ & 0 & & & & \\
\hline Coyhaique & $\begin{array}{r}9.782 \\
(120.42)\end{array}$ & $\begin{array}{r}3.996 \\
(49.19)\end{array}$ & $\begin{array}{r}2.321 \\
(28.58)\end{array}$ & $\begin{array}{r}3.227 \\
(39.73)\end{array}$ & 0 & & & \\
\hline Puerto Montt & $\begin{array}{r}3.451 \\
(34.89)\end{array}$ & $\begin{array}{r}0.761 \\
(7.70)\end{array}$ & $\begin{array}{r}3.702 \\
(37.42)\end{array}$ & $\begin{array}{c}0.214 \\
(2.17)^{*}\end{array}$ & $\begin{array}{c}1.803 \\
(18.25)\end{array}$ & 0 & & \\
\hline Laja & $\begin{array}{r}8.400 \\
(102.89)\end{array}$ & $\begin{array}{r}3.531 \\
(43.25)\end{array}$ & $\begin{array}{c}1.138 \\
(13.93)\end{array}$ & $\begin{array}{r}2.090 \\
(25.60)\end{array}$ & $\begin{array}{c}0.414 \\
(5.07)\end{array}$ & $\begin{array}{r}1.125 \\
(11.33)\end{array}$ & 0 & \\
\hline La Florida & $\begin{array}{r}12.630 \\
(154.68)\end{array}$ & $\begin{array}{r}5.711 \\
(69.95)\end{array}$ & $\begin{array}{r}5.245 \\
(64.24)\end{array}$ & $\begin{array}{r}5.815 \\
(71.22)\end{array}$ & $\begin{array}{c}0.902 \\
(11.05)\end{array}$ & $\begin{array}{r}3.893 \\
(39.19)\end{array}$ & $\begin{array}{r}2.407 \\
(29.33)\end{array}$ & 0 \\
\hline
\end{tabular}

*Non-significant.

All other parts are significant at or beyond the 0.05 level.

(Spain) stocks. No clines related to latitude were found between the Chilean stocks. Conversely, other characters such as mating ability (Brncic \& Budnik, 1984) and chromosomal inversion polymorphism (Prevosti et al., 1985, 1987, 1990) have a distinct tendency to show latitudinal clines.

On the other hand, strong differences between the eight stocks were detected in preadult viability and eggto-adult development (Table 4). The lowest viability mean was found in the Laja stock and the highest was observed in the La Florida stock. Mean egg-to-adult development time was higher in the European stocks than in the Chilean ones. Nested analysis of variance showed that only the locality of origin of the different stocks was significantly different for both parameters studied, irrespective of the continent of origin (Table 5 and 6). As has already been discussed for the wing size variable, locality turned out to be important, but not continent. We wish to emphasize the fact that the Almeria and Puerto Montt stocks in different continents were similar for all three traits studied.

\section{Discussion}

Inter-population and inter-strain differences in viability have been observed in many species of Drosophila and their adaptive significance was inferred from selection experiments (Taylor \& Condra, 1980). The importance of development time in relation to fitness was emphasized by Giesel \& Zettler (1980), who found a correla- 
Table 4 Means and standard errors of the egg-to-adult viability and development period (in days) of European and Chilean strains of D. subobscura bred at $18^{\circ} \mathrm{C}$. Fifty eggs were placed in each of 10 vials for each strain

\begin{tabular}{llll}
\hline & & $\begin{array}{l}\text { Mean number of } \\
\text { survivors per vial, } \\
\pm \text { S.E. }\end{array}$ & $\begin{array}{l}\text { Mean development } \\
\text { time (days) } \\
\pm \text { S.E. }\end{array}$ \\
\hline Locality & Latitude & $32.65 \pm 0.81$ & $28.07 \pm 0.07$ \\
Europe & $59^{\circ} 50^{\prime} \mathrm{N}$ & $30.80 \pm 1.84$ & $26.18 \pm 0.06$ \\
$\quad$ Sunne(Sweden) & $\begin{array}{l}\text { Tübingen (Germany) } \\
48^{\circ} 31^{\prime} \mathrm{N}\end{array}$ & $32.60 \pm 1.52$ & $27.10 \pm 0.08$ \\
Cinisse(Sicily, Italy) & $38^{\circ} 08^{\prime} \mathrm{N}$ & $34.50 \pm 1.31$ & $29.75 \pm 0.11$ \\
$\quad$ Almerí(Spain) & $36^{\circ} 49^{\prime} \mathrm{N}$ & $32.70 \pm 1.76$ & $28.64 \pm 0.11$ \\
Chile & & $31.30 \pm 0.79$ & $28.05 \pm 0.05$ \\
$\quad$ Coyhaique & $45^{\circ} 34^{\prime} \mathrm{S}$ & $29.50 \pm 0.83$ & $27.45 \pm 0.10$ \\
$\quad$ Puerto Montt & $41^{\circ} 28^{\prime} \mathrm{S}$ & $32.60 \pm 1.32$ & $28.67 \pm 0.12$ \\
Laja & $37^{\circ} 10^{\prime} \mathrm{S}$ & $28.10 \pm 2.10$ & $26.86 \pm 0.09$ \\
La Florida & $33^{\circ} 30^{\prime} \mathrm{S}$ & $35.00 \pm 0.89$ & $28.99 \pm 0.07$ \\
\hline
\end{tabular}

Table 5 Nested analysis of variance to estimate the influence of locality and continent on egg-to-adult viability per vial in D. subobscura (10 vials per locality)

\begin{tabular}{lrrl}
\hline Source of variation & d.f. & \multicolumn{1}{c}{$S S$} & \multicolumn{1}{l}{$F$} \\
\hline Continent & 1 & 36.45 & 0.61 \\
Locality within continent & 6 & 357.10 & $2.61^{*}$ \\
Error & 72 & 1640.40 & \\
Total & 79 & 2033.95 & \\
\hline
\end{tabular}

${ }^{*} P<0.05$.

tion with larval viability and adult longevity in $D$. melanogaster. Nevertheless, Clarke et al. (1961) found an asymmetrical response of development time to artificial selection, which suggests that in many populations egg-to-adult development time is very close to its physiological limit. Hence, the observed microdifferentiation of these traits in the recently established populations of $D$. subobscura in Chile, seems to be important.

Furthermore, we might conclude that the evolutionary process that promotes race formation is relatively rapid because colonization by $D$. subobscura is very recent and has expanded rapidly for the last 12 years (Brncic \& Budnik, 1980). The local population has diverged on the metrical characteristics analysed in this paper, and previous reports indicate inter-populational differences in mating (Brncic \& Budnik, 1984), as well as in the frequencies of structural genes and chromosomal morphs (Prevosti et al., 1985, 1987). The observed inter-populational differences are difficult to interpret in terms of causal factors, however, if we consider the nature of the analysed traits, selective processes may be invoked; historical and stochastic factors could also be involved.
Table 6 Nested analysis of variance to estimate the influence of locality and continent on egg-to-adult development period (in days) in D. subobscura

\begin{tabular}{lrrr}
\hline Source of variation & \multicolumn{1}{l}{ d.f. } & \multicolumn{1}{l}{ SS } & \multicolumn{1}{c}{$F$} \\
\hline Continent & 1 & 1.47 & 0.002 \\
Locality within continent & 6 & 3687.47 & $173.51^{*}$ \\
Error & 2558 & 9060.71 & \\
Total & 2565 & 12748.52 & \\
\hline$* P<0.0001$. & & &
\end{tabular}

The similarity between the stocks of Puerto Montt (the first locality where $D$. subobscura was found in the New World) and the population of Almeria (southwestern Spain) deserves special comment. The Chilean population might be derived from the western Mediterranean regions of the Old World. Furthermore, analysis of the chromosomal polymphorism and allozyme variation (Prevosti et al., 1985, 1987) would also suggest a western Mediterranean population as the source of American species. However, this hypothesis remains unproven because the precise origin of the American species is still unknown. During our early research on this subject, the prevailing idea was that the population was derived from the western Mediterranean (Brncic et al., 1981). However, the presence of the chromosomal arrangement $\mathrm{O}_{5}$ in the American populations, only described in northern Europe, makes this assumption uncertain; its presence in western Mediterranean populations is at present unknown. The dispersability of the species is well known (Serra et al., 1987), therefore further studies on the appearance of the chromosomal arrangement $\mathrm{O}_{5}$ in recent years in Spain is desirable. 


\section{Acknowledgements}

This research was supported by Grant B 2308/8945 from the Universidad de Chile; Fondo Nacional de Ciencias (Chile) FONDECYT 88/0044 and 90/0967. We wish to thank Professor Barrie Burnet of The University of Sheffield for his valuable assistance in the review of the manuscript. We gratefully acknowledge the help of Professor D. Sperlich of the University of Tübingen who provided the $D$. subobscura stocks from Tübingen and Sicily, and Professor A. Prevosti from the University of Barcelona and R. de Frutos from the University of Valencia, who provided the stocks of Mallorca and Almería. We wish to thank an anonymous reviewer for comments and suggestions on the manuscript.

\section{References}

BRNCIC, D. AND BUDNIK, M. 1980. Colonization of Drosophila subobscura Collin in Chile. Drosoph. Inf. Serv. USA, 55, 20.

BRNCIC, D. AND BUDNIK, M. 1984. Experiments on sexual isolation between Chilean and European strains of Drosophila subobscura. Experientia (Basel), 40, 1014-1016.

BRNCIC, D. AND BUDNIK, M. 1987. Chromosomal polymorphism in Drosophila subobscura at different elevations in Central Chile. Genetica (Netherlands), 75, 161-166.

BRNCIC, D., PREVOSTI, A., BUDNIK, M., MONCLUS, M. AND OCAÑA, J. 1981. Colonization of Drosophila subobscura in Chile. I. First population and cytogenetics studies. Genetica (Netherlands), 56, 3-9.

BUDNIK, M. AND BRNCIC, D. 1982. Colonización de Drosophila subobscura Collin en Chile. Actas V Congreso Latinoamaricano de Genética, Santiago, Chile, 177-188.

CAVICCHI, S., GUERRA, D., GIORBI, G. AND PEZzOLI, C. 1985. Temperature-related divergence in experimental populations of Drosophila melanogaster. I. Genetic and developmental basis of wing size and shape variation. Genetics, 109, 665-689.
ClARKE, J. M., MAYNARD SMITH, J. AND SONDHI, K. C. 1961. Asymmetrical response to selection for rate of development in Drosophila subobscura. Genet. Res., 2, 70-81.

COWLEY, D. E., ATCHLEY, W. R. AND RUTLEDGE, J. J. 1986. Quantitative genetics of Drosophila melanogaster. I. Sexual dimorphism in genetic parameters for wing traits. Genetics, 114, 549-566.

GIESEL, J. T. AND ZETTLKER, E. E. 1980. Genetic correlations of life historical parameters and certain fitness indices in Drosophila melanogaster: $r_{\mathrm{m}}, r_{\mathrm{s}}$ diet breadth. Oecologia (Berlin), 47, 299-302.

MCFARQUAR, A. M. AND ROBERTSON, F. W. 1963. The lack of evidence for coadaptation in crosses between geographical races of Drosophila subobscura. Genet. Res., 4, 104-131.

MISRA, R. K. AND REeVE, E. C. A. 1964. Clines in body dimensions in populations of Drosophila subobscura. Genet. Res. 5, 240-256.

PFRIEM, P. 1983. Latitudinal variation in wing size in Drosophila subobscura and its dependence of polygenes of chromosome O. Genetica (Netherlands), 65, 221-232.

PREVOSTl, A. 1955. Geographical variability in quantitative traits in populations of Drosophila subobscura. Cold Spring Harbor Symp. Quant. Biol. 20, 294-299.

pREVOSTl, A., SERRA, L., MONCLUS, M., MESTRES, F., LATORRE, A., RIBO, G. AND AGUADE, M. 1987. Colonización de América por Drosophila subobscura. Evol. Biol. (Colombia), 1, $1-24$.

prevosti, A., SERRA, L., RIBO, M., AGUADE, E., SAGARRA, E., MONCLUS, M. AND GARCIA, M. P. 1985. The colonization of Drosophila subobscura in Chile. II. Clines in the chromosomal arrangements. Evolution, 39, 838-844.

PREVOSTI, A., SERRA, L., SAGARRA, C., AGUADE, M., RIBO, G. AND MONCLUS, M. 1990. Clines of chromosomal arrangements of Drosophila subobscura in South America evolve closer to Old World patterns. Evolution, 44, 218-221.

SERRA, L., PEGUEROLES, G. AND MESTRES, F. 1987. Capacity of dispersal of a colonizing species: Drosophila subobscura. Genetica (Netherlands), 73, 223-235.

TAYLOR, C. E. AND CONDRA, C. 1980. $r$ - and $k$-selection in Drosophila pseudoobscura. Evolution, 34, 1183-1193. 